stimulating tedoher and has enabled many stidonts to achieve success in this subject. He has published many papers and has given communications and demonstrations to societies both in Britain and in the United States. He has bocome an international authority on this work. Dr. Bowman will take up his post at tho University of Stratholydo on September 1.

\section{American Association for the Advancement of Science}

DEAN DON K. PrICE, JUN., assumed offico as presidentelect of the American Association for the Advancement of Science on Tanuary 15. He is one of the few social scientists to hold this office, the most recent being the sconomist, W. C. Mitchell, in 1938. Since 1958 Don Price has been Dean of the Graduate School of Public Adminis. tration of Harvard University, and has the broad background necessary to guide the association, the wide objects of which are "to further the work of scientists, to facilitate co-operation among them, to improve the effectiveness of science in the promotion of human welfare. . .". Don I'rice was a Rhodes scholar at Oxford from 1932 to 1935 .

\section{Aid to India}

In reply to a question in the Honse of Commons on February 17, the Prime Minister, Mr. H. Wilson, said that the Governments of the United Kingdom, Canada, Australia and Now Zealand, and of sorne non-Commonwealth countries, were already in close touch with each other and with the Govornment of India regarding the threatened famine in India. Britain had made an immediate and interim contribution in the form of an interest-free loan to India of $\mathbf{f 7 . 5}$ million. The Australian Government on February 17 announced a very large ship. ment of food to India, and the problem was, above all, one of port capacity and internal distribution; some very massive shipments of food were being organized. Replying for the Prime Minister on Fobruary 24, Mr. (*. Brown added that the Government was in touch with the Indian Covernment about supplies of food which could be made available if they were needed. Discussions about further aid were still in progress.

\section{Anglo-French Co-operation in Oceanography}

Is reply to a question in the House of Commons on March 3, the Minister of State for the Department of Education and Scionce, Mr. R. F. Prentice, said that details of the French Government's intentions for undersea research had not boon made known to the British Government, but there had been unofficial exchanges between scientific organizations in the two countries, and the Secretary of State was prepared to consider any proposals that might be made. British occanographers and geographers at research establishments of the Natural Frnvironment Resoarch Council and at universities had co-operated with French scientists in such research and would continue to do so. The Natural Environment Research Council was at present reviewing the future orientation of oceanographic research in Britain. Both Britain and France, along with other countries, wero represented on the Inter-Governmental Oeeanographic Commission.

\section{Research in Mental Health}

THE debate in the House of Commons on February 18 on Mr. W. Hamling's motion to transfer responsibility for the education and training of all mentally handicapped ehildron from the Ministry of Health to the Department of Education and Scicnco was noteworthy for the repcatcd reference to the need for more research in this field. Sir David Renton, commenting on the unevenness of scientitic and social advance, pointed out that the great progress in antibiotic therapy had intensified the problem of deuling with the montally handicapped. Progress in detecting, preventing, and curing montal defects did not match the advances in antibioties and obstetries and there was immonse scope for further research. Dr. F. Summerskill also referred to tho growing magnitude of the problem and advocated the establishment of an Educational Resoarch Council. At present, only about twolve people in Britain were invostigating the learning processes of severely sub-normal children, though Dame Joan Vickers paid tribute to the, quality of some of this work. She herself suggested that the Ministries of Education, Health and Labour should set up an interdepartmental committee to reviow the scale of tho problem. Mr. J. Snow was concorned at the disparity between the scale of mental health research and the administrative action of the Ministry of Health in this field. Ho urged that more attention be paid to the problem of the autistic child. Lord Balniel strongly urged more support of research into the learning processes of backward children and referred to the work now in progress at the University of Manchester. Mr. L. Pavitt fully supported those who urged more rescarch into the problems of the montally handicapped, as did Mr. A. Muckenzie and Sir Edward Boyle, who added that the limiting factor to-day was the supply of trained workers for such rescarch. On the proposed transfer of responsibility from the Ministry of Health to the Department of Education and Science, Sir Fdward, like numerous other speakers, had roservations, while welcoming the motion gerierally. The Parliamentary Secretary to the Ministry of Hoalth, Mr. C. Loughlin, replying on the debate, warmly welcomed the pleas for more rescarch into mental health generally and promised to see that research was as far as possible extended, but he had reservations on the proposed transfor of responsibility, and the resolution was, by leave, withdrawn.

\section{Durban Museum and Art Gallery}

The director of the Durban Museum and Art Gallery reports that during 1964-65 the Dopartmont of Local History was moved from the Old Houso to the refurnished Old Court House (Annual Report of the Durban Museum and Art Gallery for the Municipal Year 1964-1965. Pp. 18. Durban: Durban Museum and Art Gallery, 1965). The Old House was later altered and redecorated and will shortly be opened as a period house. Work on the displays in the Museum was devoted to tho installation of the new geological exhibits and much lime was spent in planning the rearrangement of the Hall of South African Birds. Collecting trips included one to Northern Natal and another to tho eastorn area of Cape Province.

\section{OII and Gas Pipelines in Europe}

Tнw network of largo pipeline systoms established in Europe for the transportation of crude potrolcurn, refined produets, and gas, has now reached an advanced stage in development, which has so far taken only about 12 years to realizo. During this comparatively short period, some 1,700 miles of large diameter crude oil pipelines have been built in various systems, delivering more than 70 million tons of crude oil per annum to European refinorics. Such are the projects now planned, some well under way, that within the noxt 2 years more than 500 miles of pipeline, capable of delivering a further 50 million tons of crude oil to Central Europe each year, will, it is anticipated, be cornpleted. Implicit in this vast network nre a number of 'products pipelines' designod for the speedy transferenco of a full rango of refined petroleum products, including fuel oil, from strategically placod refinorins to the major centres of consumption, and many more such lines are already being planned. In addition, the gas industry has already completed many hundrods of milns of high-prossure gas distribution pipclines; one result of this is to make obsolete the many small individual gas-producing plants that previously existed. 